\title{
Analysis of indirect human influences and its bad impacts on ecosystems of natural forest resources (Sundarbans) in Bangladesh
}

\author{
Awal, Mohd Abdul \\ Environmental Scientist, Ministry of Environment and Forest, Founder \& Chief Advisor, Health \& Pollution Research Farm, Long Island \\ City, New York, USA
}

Email address:

abdul_awal2004@yahoo.com

To cite this article:

Awal. Mohd. Abdul. Analysis of Indirect Human Influences and its Bad Impacts on Ecosystems of Natural Forest Resources (Sundarbans) in Bangladesh. American Journal of Theoretical and Applied Statistics. Vol. 3, No. 5, 2014, pp. 130-140.

doi: $10.11648 /$ j.ajtas.20140305.13

\begin{abstract}
Sundarbans plays a vital role for human survivability from cradle to grave including tangible and intangible benefits. The total forest area of Bangladesh is about 2.47 million ha, which accounts for about $18 \%$ of the total land area of the country, and which constitutes $0.15 \%$ of the world's total tropical forests (Haque, 2000), although an estimate from 1993 only put the tree cover at $5-7 \%$ of the country's area (FAO,1993). Sundarbans comprises $45 \%$ of the total productive forests in Bangladesh, and contributes about $50 \%$ of forest related revenue (Awal, 2007). The Sundarbans is the largest single mangrove forest in the world, occupying about $6,029 \mathrm{~km}^{2}$ in Bangladesh and the rest in India (Iftekhar \& Islam, 2004). At the advent of British rule in 1765, the Sundarbans forests were double their present size (Seidensticker, and Hai, 1983; Khan, 1997). But it is facing tremendous problems (Awal, 207, 2009, 2014). However, a serious killer disease (top dying) of $H$. fomes in Sundarbans is affecting millions of the trees (Awal, 2007). The loss of $H$. fomes will have a major impact on the Sundarbans mangrove ecosystem, as well as lead to economic losses (Awal, 207, 2009, 2014). But, it is now under serious threatened through human direct and indirect destruction (Awal, 207, 2009, 2014), and by ecological pollution (Awal, 2007). The cause of this dieback is still unknown (Awal, 2007). The present work has investigated one of the possible factors that might be causing this top-dying namely the concentrations of various chemical elements present in the soil or sediments, particularly, Exchangeable K, heavy metals, though other chemical parameters such as the $\mathrm{pH}$, moisture content of the soil or sediment and nutrient status were also assessed due to indirect human destruction of Sundarbans natural resources (Awal, 2007). A questionnaire survey was conducted among different groups of people inside and outside of Sundarbans to explore local perceptions as to the possible causes of top dying (Awal, 207, 2009, 2014). This confirmed the increase in top-dying prevalence (Awal, 2007).
\end{abstract}

Keywords: Human Destruction, Indirect Extractions, Activities, Chemical Contamination, Causal Factors, Pollution, Heavy Metal Concentrations, Chemical Contamination, Sundarbans, Top-Dying

\section{Introduction}

The Sundarbans (figure 1) provide critical habitat for a diverse marine and terrestrial flora and fauna (Awal, 2007), and 3.5 million people depend on Sundarbans forests and waterways for their survival (Anon, 1986; Chaffey et al, 1985). Approximately 2.5 million people live in small villages surrounding the Sundarbans, while number of people within $20 \mathrm{~km}$ of the Sundarban boundary was 3.14 million (Islam, 1993). Bangladesh is the one of the most densely populated countries, and it has about 147.37 million people (World Fact book, July 2006) in an area of 144,000 sq Km (World Fact book, July 2006). Bangladesh is facing many problems including all kinds of environmental pollutions (Awal, 2007), high population density and poverty, these problems being interlinked with each other (Awal, 2007, 2009, 2014). These unique coastal tropical forests are among the most threatened habitats in the world (Awal, 2007, 2009, 2014; own observation staying in Sundarbans as head of east wildlife sanctuary 
from 1993-1998). They may be disappearing more quickly than inland tropical rainforests (Awal, 2007), and so far, with little public notice (Awal, 2007).

\subsection{Importance of Sundarbans Ecosystem}

The Sundarbans (figure 1) provide critical habitat for a diverse marine and terrestrial flora and fauna (Awal, 2007), and 3.5 million people depend on Sundarbans forests and waterways for their survival (Anon, 1986; Chaffey et al, 1985). Approximately 2.5 million people live in small villages surrounding the Sundarbans, while number of people within $20 \mathrm{~km}$ of the Sundarban boundary was 3.14 million (Islam, 1993). The total forest area of Bangladesh is about 2.47 million ha, which accounts for about $18 \%$ of the total land area of the country, and which constitutes $0.15 \%$ of the world's total tropical forests (Haque, 2000), although an estimate from 1993 only put the tree cover at $5-7 \%$ of the country's area (FAO,1993). Sundarbans comprises $45 \%$ of the total productive forests in Bangladesh, and contributes about $50 \%$ of forest related revenue (Awal, 2007). The 1993 total wood supply in the country was 6.2 million $\mathrm{m}^{3}$ against a demand of 8.34 million $\mathrm{m}^{3}$, with a sustainable local supply for only 1.3 million $\mathrm{m}^{3}$. Sixty five percent of forest products are consumed as fuel wood (GOB, 1993). Sundarbans supports potential fishery, honey, wood, fuel wood, thatching materials, wax, deer's meats, and resources and constitutes an important commercial and artisanal fishery industry that produces fresh fish, iced fish, sun dried fish, and smoked fish, salted fish, fish meal and sharks oil (Figure 1.0). Thus, Sundarbans provides a considerable harvest of whitefish, shrimps, prawns, mud crabs, snails / oysters and billions of shrimps, prawns, and post larvae for shrimp aquaculture farms (Awal, 207, 2009, 2014). These industries support about 155,000 fishermen throughout the year, and economic valuation of the fisheries function of mangroves was estimated to range from US\$ 66 to almost 3,000 per ha (Hambrey, 1999). Sundarbans also supports the livelihood and earnings for about two million people of the adjoining areas at least part of the year i.e. during the winter season for fishing, collection of Nypa leaf and Goran fuel wood (Hussain and Karim, 1994). The local Apis dorsata has a big commercial importance (Awal, 2007, 2009, 2014; own observation staying in Sundarbans as head of east wildlife sanctuary from 1993-1886). Traditional honey hunting is an interesting item for the tourists operated during April to July each year (Awal, 207, 2009, 2014). About 30,000 kg of honey and $80,000 \mathrm{~kg}$ of raw wax are harvested annually (Islam, 1993). These products are widely used in the pharmaceutical industries (Awal, 207, 2009, 2014).According to Guha (1989), historically there has been the transformation of resource utilization patterns by both the relevant government departments and traditional users. Paramount among these changes were shifting from communal to individualized forms of use, as encouraged by the permit system and by leasing rights and employment practices introduced by the Forest Department (Awal, 207,
2009, 2014).

\subsection{Indirect Human Influence}

Sundarbans plays a vital role for human survivability from cradle to grave including tangible and intangible benefits (Awal, 2007). Coastal lands include some of the most productive ecosystems and have a wide range of natural functions (Awal, 2007). Wetlands are also one of the most threatened habitats because of their vulnerability and attractiveness for 'development' (Awal, 2007). The first global conservation convention (Ramsar Convention) focused solely on coastal lands and wetlands like Sundarbans( figure 1), and this Convention has recently been strengthened and elaborated with regard to the wise use of all coastal forests such as Sundarbans (Awal, 2007, 2009, 2014).

Sundarbans protects people and resources from strong tidal surges, hurricanes, tides and from waves. Progressive reclamation of the Sundarbans over the last 150 years has resulted in the loss of substantial masses of mangrove forests.

Bangladesh is a poor country, the size of Wisconsin, bursting with a population nearly half (of the total population) of the United States. On top of rampant illiteracy, poverty, corruption and disease, the country suffers year after year from devastating natural disasters (Awal, 2007; Emilie, R; and Sandhya, S, 2006).

Recently, it has been suggested that global climate change will increase the intensity of cyclones that form over the Bay of Bengal, sending more violent storm surges crashing into the coastal belts of Bangladesh (Awal, 2007). The salt water front will crawl further inland, rendering farm and other lands unusable and polluting much of the fresh water all over the country (Emilie,R; and Sandhya, S, 2006; Awal, 2007). The Sundarbans might be wiped out, and most alarmingly, as much as 18 percent of the land could slip into the bay in the next 100 years because of rising sea level due to global warming and climatic change, according to the World Bank, which might displace as many as 30 million people in Bangladesh (Emilie,R; and Sandhya, S, 2006; Awal, 2007). The major portion of the land is low with a maximum height of $10 \mathrm{~m}$ above mean sea level (Alam, 1990). Every year, tornados strike at peoples, buildings, plants and wildlife in the coastal belt at the beginning and end of autumn season (Awal, 2007).

Although less obvious than habitat loss, the indirect effects of agriculture on mangroves, though the diversion of freshwater by agriculture irrigation schemes, or run-off of agricultural chemical residues into mangroves, have also been significant factors associated with deteriorating mangrove conditions in the Indus Delta and in the western part of the Sundarbans (Chaffey, Miller and Sandom, 1985). Although very little information is available, there is great concern in Asia regarding environmental impacts from agricultural pesticides, some of which are known to be highly toxic to shrimp (Phillips, 1994), as well as concern about the consumption of aquaculture products which can 
expose consumes to high levels of contaminants (Pullin, 1993). Bangladesh experiences many kinds of pollution (Emilie,R; and Sandhya, S, 2006; Awal, 2007), and this is likely to affect ecosystems as well as human health (Awal, 2007, 2009, 2014).

\section{Methodology}

Nine plots were selected for sampling, choosing areas to reflect different intensities of top-dying. Sixty-three sediment samples were tested for the various parameters, including $\mathrm{x}$ elemental concentrations being determined by ICP-MS. The relationships between top-dying and chemical or growth parameters were tested using correlation coefficients, the variations between plots were tested using analyses of variance and differences in seedling and sapling numbers using chi-square statistics. Results of seedling and sapling

regeneration showed a marked reduction in numbers in areas with greater concentrations of several chemical parameters. However, adult tree growth was generally not correlated with the chemical parameters. Also, most of the individual elements and parameters studied had no significant correlation with the average intensity of top-dying of Heritiera fomes. However, exchangeable $\mathrm{K}$, sediment moisture content and sediment $\mathrm{pH}$ were significantly related and $\mathrm{Sn}, \mathrm{Pb}, \mathrm{Zn}$ and $\mathrm{Ni}$ were also close to significance. These results show that the chemical composition of the soil appeared to be an important factor related to tree regeneration, though not to adult tree size, and in some cases to be related to the top-dying of Heritiera fomes in Sundarbans. It is suggested that the latter effect is due to a weakening of the vigor of the trees, allowing other factors such as pathogenic agents to attack the plants.

\subsection{Field Sampling Methods}

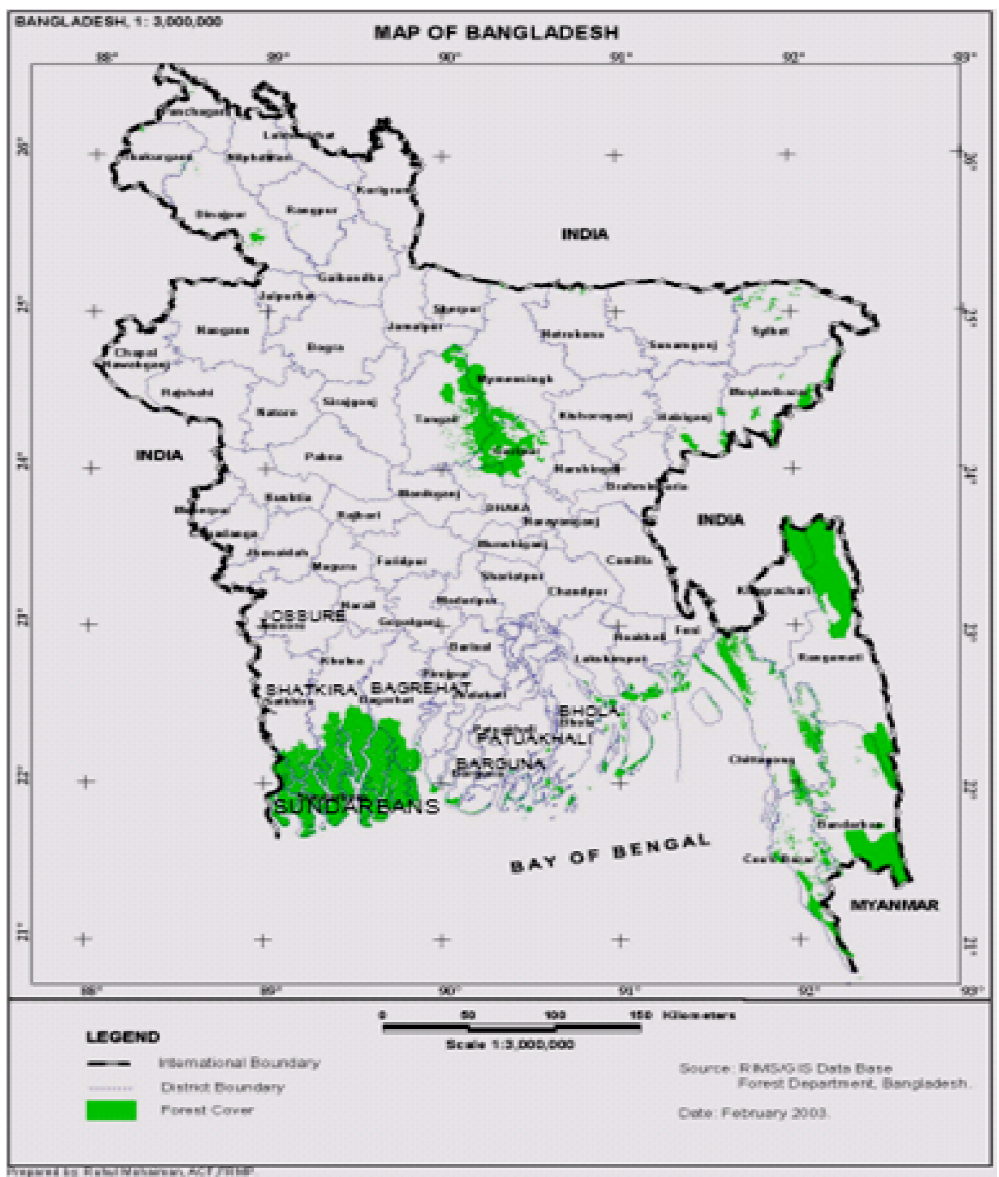

Figure 1.0. Map showing the administrative districts of Bangladesh, including the location of the Sundarbans (the shaded area in the south-west of the country)

Fieldwork was performed between October 2003 and March 2004. Sampling was done from the area of the Sundarbans near Chandpai, which is the area most accessible to people and also potentially the one that is most polluted (Figure 2.0). Three areas (termed 'compartments') from this region were selected (numbers 26, 28 and 31) because they were believed to represent a range of severity of top-dying disease as well as of human activities, as outlined in Awal et al. (2009). Within each of the three compartments, sampling of vegetation, mangrove sediment and water took place within three $20 \mathrm{~m} \times 20 \mathrm{~m}$ plots, chosen to reflect a range of top-dying intensities (high, medium and low for that area). 


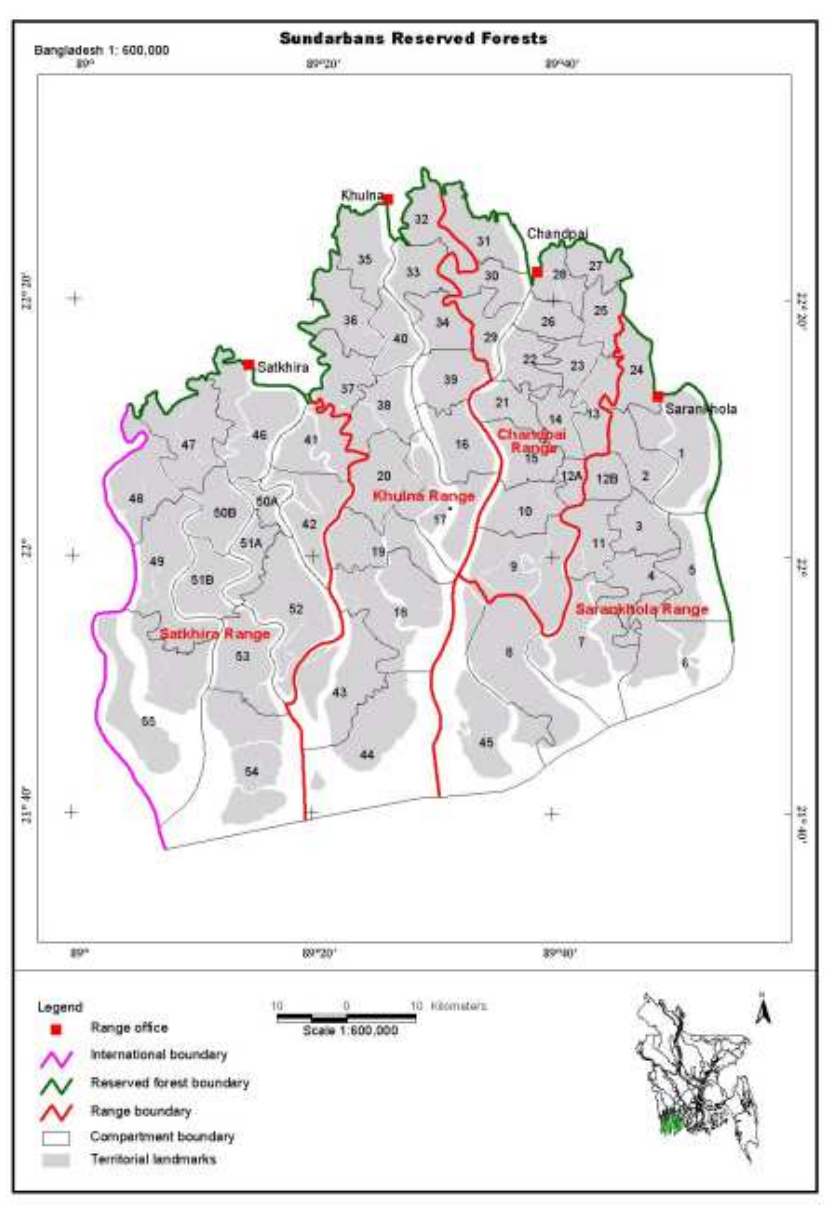

Figure 2.0. Shows compartment numbers and Ranges of Sundarbans Reserved Forest.

The sampling was conducted in a randomized block design, in that a plot was sited within a particular top-dying intensity block, but the precise location of that plot was randomized so as not to bias the detailed data collection. Therefore a total of nine plots were sampled. It should be noted that the material making up the mangrove sediments will include marine, coastal and freshwater deltaic sediments as well as biological material such as tree litterfall. The relative importance of these sources will depend to a great extent on the patterns of river discharge (Dyer, 1986) and the extent of tidal inundation, and will also therefore vary spatially throughout the Sundarbans.

From each of the nine plots, one water sample was collected in a plastic bottle from a nearby river, creek or channel. Also, seven sediment samples were collected per plot; one from the centre of the plot, four (one each) from all the corners, and two from the middle sides of the plot. Therefore a total of 63 sediment samples were taken. These mangrove sediment samples were collected from 0-30 cm depth by using a stainless steel spatula and steel cylinder $(d=5.25 \mathrm{~cm})$, and all samples were kept in sealed plastic bags until sample preparation took place. Samples were preserved in portable coolers until arrival at the laboratory at Dhaka University for initial chemical analysis and air drying. This field sampling method followed the W.H.O,
U.K, and E.P.A systems of standard laboratory and field sampling principles, rules and regulations. The dried samples were later transported to Bradford, U.K., for chemical analysis by ICP-MS. Within each of the nine $20 \mathrm{~m}$ $\mathrm{x} 20 \mathrm{~m}$ plots, each adult tree of all species was assessed for three parameters. The diameter at $1 \mathrm{~m}$ height was recorded (in $\mathrm{cm}$ ) by using a measuring tape or slide calipers, depending on girth. The tree height to the top of the crown was determined mainly by ocular estimation, but some heights were checked by using clinometers at a set distance of $20 \mathrm{~m}$ to test the accuracy of such ocular estimations. Thirdly, the status of the tree in respect of the amount of top-dying was assessed by using a four point qualitative scale of intensity, namely; not affected, mildly affected, moderately affected or highly affected by top-dying (Figure 2). This was later expressed as a semi-quantitative or rank scale and used as an index of top-dying intensity in that plot. After assessing the adult trees, the total number of seedlings (individuals of the tree species $<1 \mathrm{~m}$ tall), and saplings (young trees $>1 \mathrm{~m}$ tall with a diameter of trunk of $<10 \mathrm{~cm}$ ), of all species were counted within the plots. Care was taken to ensure that trees, saplings and seedlings were not counted more than once or missed in the recording process by marking them, using different colors for adult and regenerating trees.

\subsection{Laboratory Analyses}

Initial chemical and physical properties of the mangrove sediment samples and the water were determined in Dhaka University. These were the electro-conductivity for the determination of sediment and water caution exchange capacity; the $\mathrm{pH}$ of both sediment and water; the percentage moisture content of the sediments; soil particle analysis determined by a Plunger Hydrometer; the concentrations of S, soluble $\mathrm{N}$ (digestion method), and total $\mathrm{N}$ (Kjeldahl method. All remaining elemental concentrations were determined using Inductively Coupled Plasma - Mass Spectrometry (ICP-MS) at Bradford University.

\subsection{Electro-Conductivity}

Fifty $\mathrm{ml}$ of distilled water was added to (how much of?) the sediment, and the mixture shaken mechanically and then stirred 5-7 times to ensure thorough mixing. The sediment suspension was left overnight for it to reach its stable suspension position phase. Finally water EC was recorded by using an EC meter.

\section{4. $\mathrm{pH}$}

The $\mathrm{pH}$ of the sediment samples was measured by adding $50 \mathrm{ml}$ of distilled water to [how much?] the sediment, then shaken and stirred 5-7 times to ensure thorough mixing. The mixture was left overnight for it to reach its stable suspension position phase before recording the $\mathrm{pH}$ using a $\mathrm{pH}$ meter. For the $\mathrm{pH}$ of the water samples, $50 \mathrm{ml}$ each of water sample and distilled water were taken, 
stirring was done in the same way as for the sediment $\mathrm{pH}$ measurement, and the sample solution left overnight before filtering using a Whatman No. 42 filter paper and then recording the $\mathrm{pH}$ as above.

\subsection{Particle Size Analysis}

Each sediment sample was air dried, ground to a powder, sieved, and then reacted with hydrogen peroxide solution $\left(\mathrm{H}_{2} \mathrm{O}_{2}\right)$, according to the procedure described in Black et al. (1965). In the hydrometer, the blank reading was taken after 40 seconds, and the second reading after two hours, maintaining the temperature at $29^{\circ} \mathrm{C}$; and these values were used to calculate the particle size (Black et al., 1965).

\subsection{Percentage Moisture Content of the Sediment}

Approximately $50 \mathrm{~g}$ of sediment was passed through a 2 $\mathrm{ml}$ sieve. The sieved material was then weighed and heated to $105^{\circ} \mathrm{C}$ for 24 hours to dry it completely. The dry sediment was then reweighed and the difference in weights gave the weight of moisture. This amount of moisture was expressed as a percentage of the original wet sediment weight.

\subsection{Elemental Concentrations by ICP-MS}

Initial sample preparation was performed at Dhaka University. Adhering materials were removed with forceps, and all sample materials were dried at ambient temperature and were disaggregated to pass a laboratory test sieve using a brush. Soil samples were ground by an acid proof porcelain mortar pestle using a porcelain hammer. After making the soil into powder, samples were kept in plastic bags until later analysis. Subsequent analyses of the dried sediment samples were performed at Bradford University. In all steps of soil sample preparation and analysis, care was taken to avoid contamination. All items of equipment were first washed by hot tap water, soapy water, cold water, then by demonized water or distilled water and finally with acid leached in demonized water. For drying, all items were kept for 12 hours in an oven, and then they were washed again by the same procedure before storing, to be washed again immediately prior to starting a new analysis. Instruments were cleaned with appropriate blanks before beginning every experiment.

The 63 samples, together with two reference materials (namely peach leaf, 1547 NIST, and estuarine sediment, 1646 NBS) and blanks as controls were prepared by adding $4 \mathrm{ml}$ of concentrated $1 \mathrm{M} \mathrm{HNO}_{3}$ solution to $0.2 \mathrm{~g}$ of the sample and pre-digested until the reaction of volatile or easily oxidized materials had subsided. Fresh blank samples were made for each separate set of acid digestions. Soil samples were digested by a Microwave Digestion System (MDS). All samples and solutions of material were kept in a cool room (at approximately $5^{\circ} \mathrm{C}$ ) until they were used for analysis. The samples were then sealed in Advanced Composite Vessels with a rupture membrane and pressure control cover in each, and heated in a microwave oven. The samples were heated slowly up to $103^{\circ} \mathrm{C}$, maintaining 175 psi pressure for 12 minutes. The resultant digest was cooled and collected by washing seven times with double-distilled water, filtered, then transferred to a volumetric flask and diluted to make $250 \mathrm{ml}$ volume. The samples were then analyzed for 32 elements, this paper focusing on the 25 listed in Table 2 (list here if not giving the table in detail: $\mathrm{Al}, \mathrm{As}, \mathrm{B}, \mathrm{Ba}, \mathrm{Bi}, \mathrm{Ca}, \mathrm{Cd}, \mathrm{Co}, \mathrm{Cr}, \mathrm{Cu}, \mathrm{Fe}$, $\mathrm{Hg}$, In, K, Mg, Mo, Mn, Na, Ni, P, Pb, Rb, Sb, Sc, Se, Si, $\mathrm{Sn}, \mathrm{Sr}, \mathrm{Ti}, \mathrm{V}, \mathrm{Y}, \mathrm{Zn}$, though we could leave out some of the less relevant elements such as In, Rb, Sc and Y) using ICPMS. Calibration standards were required for checking the detector response, and these were prepared with known quantities of the elements at five concentrations $(1,10,100$, 200 and $1000 \mathrm{ppb}$ ) to cover the range of concentrations likely to be found for each element. The calibration standards are typically prepared using $2 \% \mathrm{HNO}_{3}$, but early trials suggested that there might be retention and crosscontamination of $\mathrm{Hg}$ within the equipment using this acid, and therefore 200 ppb gold-wash solution was used instead which improved instrumental response (details in Awal, 2007).

\subsection{Statistical Analysis}

Data on the severity of top-dying for each tree in a plot, which had been recorded as 'not affected', 'mildly affected', 'moderately affected', and 'highly affected', were converted into a four-point scale (0-3), so that they could be summed and an average (median) could be determined for each plot, thus producing an average index score per plot based on ranked data. Comparisons of the strength of relationship between two variables were assessed by correlation: the Pearson's product-moment correlation coefficient where both variables were fully quantitative or the Spearman's rank correlation coefficient where the topdying index was one of the variables. In the case of the Spearman's coefficient, the probability of the outcome was determined by using the approximation to a t-statistic appropriate to these tests (Sokal and Rohlf, 1981). The Spearman's correlation was used here because the topdying data are based on an index, and probably not meeting all the assumptions of truly parametric data, although since the elemental concentrations are fully quantitative data, using this statistic will result in some information loss.Data on frequencies of seedlings or saplings in each of the plots and compartments were tested by $\chi^{2}$ contingency table analyses to determine whether the amount of top-dying was associated with location. A similar consideration of the different compartments as comprising one factor, and the plot type as a second, was used to test the pattern of elemental concentrations and other variables by a twofactor analysis of variance test with replication. This allows an assessment of the significance, not only of the two factors separately but also of the interaction between the two factors (Zar, 1984). It should be noted that the plot type was not a strictly controlled factor, since the three categories of top-dying intensity were relative to each other 
within any one compartment and might not have been exactly equivalent between the three categories in different compartments; interpretation of the results from these test therefore needs to bear this in mind. MINITAB version 14

Statistical Software has been used for all data analysis.

\section{Results}

Table 1.0. Mean ( \pm 1 S.E.) and extreme heavy-metal elemental concentrations (ppb) in Sundarbans, together with comparisons with values from other published sources. An asterisk denotes a value below the limits of detection. Comparable data could not be found for all elements.

\begin{tabular}{|c|c|c|c|c|c|}
\hline \multicolumn{5}{|c|}{ Values from this study } & \multirow{2}{*}{$\begin{array}{l}\text { Values reported elsewhere } \\
\text { (Data refer to sediments unless otherwise stated; number within brackets } \\
\text { indicates source in footnote) }\end{array}$} \\
\hline Element & Minimum & Mean & S.E. & Maximum & \\
\hline $\mathrm{Al}$ & 0.89 & 16332.44 & 854.17 & 37570.00 & $420-585\left(\right.$ soil,$\left.^{1}\right) ; 8089000-46100000\left(^{1}\right) ; 500$ (spring and well water, $\left.{ }^{2}\right)$ \\
\hline As & $*$ & 4.56 & 0.24 & 10.06 & $3150-6830\left(^{7}\right)$ \\
\hline $\mathrm{B}$ & 0.55 & 19.20 & 2.14 & 103.80 & 2600 (spring and well water, ${ }^{2}$ ) \\
\hline $\mathrm{Ba}$ & 0.59 & 52.41 & 2.37 & 141.80 & 300 (spring and well water, $\left.{ }^{2}\right) ; 141$ (coastal soils, $\left.{ }^{5}\right)$ \\
\hline $\mathrm{Bi}$ & $*$ & 0.40 & 0.02 & 0.74 & \\
\hline $\mathrm{Cd}$ & 0.15 & 0.55 & 0.03 & 1.62 & $0.52-0.92\left(\right.$ soil $\left.^{1}\right) ; 300-13520\left(^{1}\right) ; 43-147\left(^{4}\right) ; 0.8\left(\right.$ coastal soils, $\left.^{5}\right) ; 11-65\left(^{7}\right)$ \\
\hline $\mathrm{Co}$ & 5.93 & 31.31 & 5.65 & 143.60 & $0-7.9\left(\right.$ ocean water $\left.^{3}\right) ; 3800-26000\left({ }^{1}\right) ; 10.6\left(\right.$ coastal soils, $\left.{ }^{5}\right) ; 5540-15500\left(^{7}\right)$ \\
\hline $\mathrm{Cr}$ & 3.11 & 15.72 & 3.39 & 114.90 & $\begin{array}{l}\left.\left.7\left(\text { spring and well water, }{ }^{2}\right) ; 1480-8560\left(^{4}\right) ; 41.2 \text { (coastal soils, }{ }^{5}\right) ; 12.8 \text { (water, }{ }^{6}\right) \text {; } \\
33200\left({ }^{6}\right) ; 19500-46100\left(^{7}\right)\end{array}$ \\
\hline $\mathrm{Cu}$ & 1.85 & 10.52 & 1.71 & 43.76 & $\begin{array}{l}12.2-16.6\left(\text { soil }^{1}\right) ; 12940-85600\left(^{1}\right) ; 22\left(\text { spring and well water, }{ }^{2}\right) ; 22-37.2 \\
\left(\text { ocean water, }{ }^{3}\right) ; 2270-14730\left({ }^{4}\right) ; 23.1\left(\text { coastal soils, }^{5}\right) ; 3.8\left(\text { water, }^{6}\right) ; 18200\left(\left(^{6}\right) \text {; }\right. \\
6950-31600\left(^{7}\right)\end{array}$ \\
\hline $\mathrm{Fe}$ & 25.82 & 173891.10 & 9883.85 & 248200.00 & $\begin{array}{l}634-820\left(\text { soil }^{1}\right) ; 8080000-52000000\left(^{1}\right) ; 63\left(\text { spring and well water, }{ }^{2}\right) ; 6.2- \\
131.5\left(\text { ocean water, }^{3}\right) ; 38.5\left(\text { water, }^{6}\right) ; 7110000\left(^{6}\right)\end{array}$ \\
\hline $\mathrm{Hg}$ & * & 6.41 & 1.47 & 83.30 & $66-180\left(^{4}\right) ; 1.8\left(\right.$ water $\left.^{6}\right) ; 6320\left(\left(^{6}\right)\right.$ \\
\hline $\mathrm{Mn}$ & 0.70 & 436.80 & 14.69 & 697.00 & $\begin{array}{l}4980-438000\left({ }^{1}\right) ; 25\left(\text { spring and well water, }{ }^{2}\right) ; 1.8-40.8\left(\text { ocean water, }^{3}\right) ; 3738 \\
\left(\text { coastal soils, }{ }^{5}\right) ; 7.4\left(\text { water, }^{6}\right) ; 412000\left(^{6}\right)\end{array}$ \\
\hline Mo & 0.20 & 1.62 & 0.46 & 26.15 & 24 (spring and well water, ${ }^{2}$ ) \\
\hline $\mathrm{Ni}$ & 7.58 & 76.08 & 18.84 & 1127.00 & $\begin{array}{l}\left.10800-37400\left(^{1}\right) ; 3\left(\text { spring and well water, }{ }^{2}\right) ; 0-12.1 \text { (ocean water, }{ }^{3}\right) ; 24.5 \\
\left(\text { coastal soils, }{ }^{5}\right) ; 15900-44600\left(^{7}\right)\end{array}$ \\
\hline $\mathrm{Pb}$ & 0.32 & 19.30 & 0.98 & 34.19 & $\begin{array}{l}1.0-1.76\left(\text { soil }^{1}\right) ; 1460-10400\left({ }^{1}\right) ; 2\left(\text { spring and well water, }{ }^{2}\right) ; 3440-15590 \\
\left({ }^{4}\right) ; 74.0\left(\text { coastal soils, }^{5}\right) ; 2.3\left(\text { water, }^{6}\right) ; 12800\left({ }^{6}\right) ; 8046-15700\left(^{7}\right)\end{array}$ \\
\hline $\mathrm{Rb}$ & 0.18 & 36.37 & 1.65 & 76.94 & \\
\hline $\mathrm{Sb}$ & $*$ & 0.09 & 0.05 & 2.93 & $30-94\left({ }^{7}\right)$ \\
\hline $\mathrm{Sc}$ & * & 6.05 & 0.37 & 8.98 & \\
\hline $\mathrm{Se}$ & $*$ & 0.17 & 0.05 & 1.43 & \\
\hline $\mathrm{Sn}$ & * & 0.61 & 0.16 & 9.68 & $219-654\left(^{7}\right)$ \\
\hline $\mathrm{Sr}$ & 0.18 & 27.77 & 0.89 & 44.17 & 2200 (spring and well water, ${ }^{2}$ ) \\
\hline $\mathrm{Ti}$ & 4.61 & 475.39 & 26.26 & 1350.00 & $72-341\left(^{7}\right)$ \\
\hline $\mathrm{V}$ & 0.09 & 32.93 & 1.14 & 51.65 & 13 (spring and well water, $\left.{ }^{2}\right) ; 18500-46900\left(^{7}\right)$ \\
\hline $\mathrm{Y}$ & 0.03 & 6.60 & 0.34 & 16.69 & \\
\hline $\mathrm{Zn}$ & 2.30 & 73.60 & 2.23 & 112.50 & $\begin{array}{l}35.0-56.2\left(\text { soil }^{1}\right) ; 120-62200\left(^{1}\right) ; 2.4-20\left(\text { ocean water, }^{3}\right) ; 72.5\left(\text { water, }{ }^{6}\right) \\
43200\left(^{6}\right) ; 24300-76000\left(^{7}\right)\end{array}$ \\
\hline
\end{tabular}

${ }^{1}$ Balasubramanian, 1999. ${ }^{2}$ Bond, R G \& Straub, C P (eds), $1973{ }^{3}$ Braganca \& Sanzgiri, 1980. ${ }^{4}$ IUCN Reports $1987 .{ }^{5}$ McGrath \& Loveland (1992). ${ }^{6}$ Sarkar, S.K. et al. 2003 ( Premonsoon data from the mouth of the Ganga estuary near Gangasagar used). ${ }^{7}$ Zöckler, C \& Bunting, G 2006.

The results of the analyses of the basic soil and water parameters such as percentage moisture content, $\mathrm{pH}$ and EC are presented in different tables.

Table 2.0. General Linear Model for the Soil Nutrient parameters in Sundarbans: Analysis of Variance results, testing for the two factors of Compartment and Plot, together with their interaction. Values given are the F-results together with probability levels. (Significant results are indicated with asterisks). (Key: $p>0.05$, N.S. ; $p<0.01$,**; $p<0.001, * * *$ ).

\begin{tabular}{|c|c|c|c|}
\hline Soil Nutrients Element & Compartment F $(2,46)$ & Plot F $(2,46)$ & Interaction $\mathrm{F}(\mathbf{4 , 4 6 )}$ \\
\hline $\mathrm{Na}$ (Sodium) & $4.65, \mathrm{p}=0.014 * *$ & $2.14, p=0.13, \mathrm{NS}$ & $1.23, \mathrm{p}=0.31, \mathrm{NS}$ \\
\hline Exc. $\mathrm{Na}$ & $3.47, \mathrm{p}=0.039, * *$ & $0.22, \mathrm{p}=0.80$, N.S & $1.08, \mathrm{p}=0.38, \mathrm{~N} . \mathrm{S}$ \\
\hline Soluble-Na & $3.77, \mathrm{p}=0.031 * *$ & $2.20, \mathrm{p}=0.12$, N.S. & $0.17, p=0.95, \mathrm{NS}$ \\
\hline Soil pH & $11.67, \mathrm{p}=0.000 * * *$ & $2.71, \mathrm{p}=0.07 * *$ & $7.46, \mathrm{p}=0.000 * * *$ \\
\hline S (Sulphur) & $4.51, \mathrm{p}=0.016^{* *}$ & $0.32, p=0.73$, N.S. & $1.86, p=0.13, N . S$ \\
\hline $\mathrm{Ca}$ Calcium & $0.37, p=0.69$, N.S & $2.17, p=0.13$, N.S. & $1.60, p=0.19$, N.S. \\
\hline (Soluble) K (Potassium) & $1.67, p=0.20$, N.S. & $0.67, p=0.52$, N.S. & $1.64, p=0.18$, N.S. \\
\hline Exc. K (Exchangeable - Potassium) & $5.15, \mathrm{p}=0.01 * *$ & $1.15, p=0.33$, N.S. & $0.80, p=0.53$, N.S. \\
\hline N (Total Nitrogen) & $0.63, p=0.54$, N.S. & $0.70, p=0.50$, N.S. & $1.02, p=0.40$, N.S. \\
\hline N (Soluble Nitrogen) & $0.32, p=0.73$, N.S. & $0.34, p=0.72$, N.S. & $0.80, p=0.53$, N.S. \\
\hline Fe ( Iron) & $0.38, \mathrm{p}=0.69, \mathrm{NS}$ & $1.58, \mathrm{p}=0.22, \mathrm{NS}$ & $0.74, p=0.57, \mathrm{NS}$ \\
\hline
\end{tabular}


Table 3.0. Outcomes from the analyses using Spearman's Rank Correlation Coefficient of the relationship between severity of top-dying and various parameters of tree structure and growth (Key: $N S=p>0.05 ; *=p<0.05$ ).

\begin{tabular}{llll}
\hline Parameters comparing with Top-dying. & Correlation (r-value, with7df). & Probability (p-value) & Sig. or N. S \\
\hline Tree height $(\mathrm{m})$ & -0.113 & 0.773 & N.S \\
Tallest tree height $(\mathrm{m})$ & 0.072 & 0.854 & N.S \\
Bole diameter $(\mathrm{cm})$ & 0.067 & 0.865 & N.S \\
Tree density $\left(\mathrm{m}^{2}\right)$ & 0.021 & 0.956 & N.S \\
Soil Moisture Content Percentage (M.C. \%). & -0.736 & 0.024 & $*$ \\
\hline
\end{tabular}

\section{Discussion}

Various authors have reported the top-dying of Sundri trees in the Sundarbans at different times, notably Toup (1921), Curtis (1933), Forestal (1960), and Gibson (1975). On the basis of their observations, these and other authors have at various times suggested several possible hypotheses to explain the cause of the observed top-dying.

A wide range of arguments had been put forward concerning edaphic changes in Sundarbans. These included reduction in flow of fresh water throughout the Sundarbans because of withdrawal of water at Farakka Barrage and resultant increase in soil and water salinity (Shafi, 1982), reduction in siltation (Chowdhury, 1984), increase in siltation (Sattar, 1977), etc. These edaphic changes have been suggested to be responsible for top- dying. It may be noted that most of the suggestions were not based on experimental data, for example Banik (2000).

Chowdhury (1984) stated that the reduction of fresh water discharges through the Sundarbans was due to (a) the diversion of the upstream Ganges water and (b) more use of upstream water for irrigation and industrial use. Previously the rivers of the area were very active and used to lay freshly deposited silts on top soil every year where Sundri would survive well. But with the reduction in discharge of fresh water, silt carrying capacity of the river has also been reduced. Previously these areas were well drained at ebb tides but now due to change in river regime due to the Farakka barrage, the drainage patterns including flow characteristics have been changed. Consequently the trees are becoming thinner and shorter.

Sundri (Heritiera fomes) lacks the ability to exract fresh water from salt water at even a relatively low salt concentration (Hoffman et al., 1986). Balmforth (1985), based on the report of Chaffey et al., (1985), stated that the primary cause of Sundri top-dying was the increase in soil salinity. Withdrawal of Ganges water at Farrakka because of the dam construction in 1976 was, in his opinion, one of the possible causes for the increase in salinity in the Sundarbans. Balmforth's statement regarding the causes of Sundri top-dying due to an increase in salinity was, however, not supported by his data. Moreover, the data presented by Chaffey et al., (1985), from examined soil samples collected from 20 sites including top-dying and healthy Sundri areas in the Sundarbans, are not in agreement with Balmforth's statement, nor with the conclusion of Chaffey et al., (1985) themselves. These authors had suggested that soil salinity was higher on sites affected by top-dying than on unaffected sites, and that therefore an increase in soil salinity is an important factor in the onset of top-dying. However, severely affected top-dying areas are, in fact, distributed in slightly saline to non-saline zones as presented by Chaffey et al. (1985). Thus a total of $18 \%$ of Sundri trees with d.b.h above $5 \mathrm{~cm}$ had been affected by topdying of Sundri in Sundarbans (Chaffey et al., 1985). Only a very small number of top-dying affected Sundri were present in the salt water zone (Chaffey et al., 1985); 13-15\% in moderately salt water zone, $21-24 \%$ in salt water zones and $25-47 \%$ in the fresh water zone respectively. This contrast with results of Ismail (1987), who stated that soil salinity, was higher on sites affected by top-dying than on unaffected sites, suggesting that soil salinity is an important factor in the onset of top-dying.

Sattar (1977) inferred that mortality of Sundri is possibly due to edaphic changes such as heavy siltation, increase in salinity, less flooding by fresh water, and alteration in the frequency and duration of inundation. However, the decline of more salt tolerant species suggests that the cause of decline of the Sundri is not primarily due to insufficient fresh water flow during the dry season.

Christensen (1984) stated that salinity may not be a direct cause of top-dying but is an indicator of many geochemical processes that have an impact on living organisms (e.g. by affecting nutrient availability).Hassan (1988) provided data on soil and water salinity of a number of sites in the Sundarbans. He also studied the effect of salinity of Sundri seedlings in a simulated experiment. The data on salinity was compared with those of Chaffey et al., (1985). It was observed that the top-dying did not show any consistent relationship with the salinity. Hassan (1988) reported that soil salinity in the Sundarbans varies between less than 2000 micro mhos to more than 4000 micro mhos, which rise up to about 6000 micro mohs during the lean period in April. Hassan (1988) also observed that Sundri top-dying did not show any consistent relationships with salinity. Moreover, regeneration and survival of Sundri seedlings did not show any change due to water salinity variation between the range 1,000 to 49,000 micro mhos under experimental conditions (Hassan et al., 1990). 1Therefore, Hassan et al., (1984) provided a detailed report on soil and salinity of the Sundarbans in relation to topdying, regeneration and survival of Sundri. They did not observe any consistent relationships between top-dying and salinity. Regeneration and survival of Sundri seedlings also did not show any relationships to the salinity variation between 1,000 to 49,000 micro mohs under simulated conditions (Hassan, et al., 1990). 
Accordingly Shell and Ross (1987) studied the $\mathrm{Na}^{+}$and $\mathrm{K}^{+}$levels in Sundri tissues and found that: (a) the $\mathrm{Na}^{+} / \mathrm{K}^{+}$ ratios in the tissues of healthy trees appear to be related to the salinity of their local environment; (b) the average percentage of $\mathrm{Na}^{+}$and $\mathrm{K}^{+}$was not significantly different in healthy and dying Sundri trees; (c) though some link was indicated between top-dying and ionic balance in plant tissue, it was not possible to resolve the causal factor and its effect. According to Lugo and Snedaker (1974), gross primary productivity of mangroves increases with the availability of fresh water. The fresh water input to the estuary is associated with physical, chemical, geological and biological melange, fauna and flora of the estuary / coastal zone. This input tends to enrich the sites (Snedaker et al., 1977). Imam (1982) noted that a system analysis and simulated studies on the ecology of mangrove forests in Florida, USA, had demonstrated that terrestrial water plays a vital role in the development of mangrove biomass, which in turn reflects the gross photosynthesis. It has been construed that both mangrove zonation and vigour are functions of nutrient availability rather than salinity alone.

On the basis of the above findings Sheil and Ross (1987), concluded that these observations are compatible with a pathogenic cause of top-dying as forwarded by Rahman et al., (1983; see next section). This means that in their opinion salinity is not the causal factor for the top-dying.

More recent research on the association between salinity and top-dying of Hetiera fomes has concluded that it is not the causal factor previously thought. Hassan et al. (1990) suggested that there is no relationship between salinity and top-dying of Sundri, and data of Rahaman et al. (2003), where soil salinity was estimated in terms of the level of sodium $(\mathrm{Na})$ and electrical conductivity, revealed that there is no significant variation in the mean value of $\mathrm{Na}$ and $\mathrm{EC}$ in soil of the Sundarbans.

According to Gupta et al. (1986), reporting on the salt tolerance of some tree species at the seedling stage, the salinity ranges which prevail in the Sundarbans are tolerable even to some mesophytes such as Eucalyptus camaldulensis and Acacia nilotica. This observation contradicts with the inference that a species such as Sundri should be seriously affected by the salinity observed. Moreover, without a governing cause top-dying could not merely increase with time, as suggested by Chaffey et al. (1985), indicating that salinity alone can not be the cause of top-dying of Sundri.

Chaffey (1985) reported that reduction in the number of lenticels on the pneumatophores might be associated with top-dying of Sundri. Accordingly, a study was carried out in which the numbers of lenticels were counted under a magnifying lens on 90 sq. $\mathrm{cm}$ area of the pneumatophores of nine top-dying and nine healthy Sundri trees, selected randomly from relatively fresh water zone at Burigolini. Actually, the results indicated that there was no relation between the number of lenticels on the pneumatophores and the top-dying.

Pathological studies on top-dying of Sundri were conducted by Rahman et al. (1983, 1986). Based on these and other studies conducted so far (reviewed in Rahman et al., 1986) there does not appear to an association between pathological factors and top-dying. According to Rahman et al. (2001), a precise description of symptoms of any plant is important for further study leading to disease prevention. The same is true in case of top-dying of Sundri as well.

Therefore, trees were labelled in each of the damage categories (Rahman et al., 2001). After that the labelled trees were observed to identify the symptoms of top-dying on the various branches at the time of recording within the selected plots. Subsequently, observations at monthly intervals were recorded of the symptoms of top-dying on the branches and progressive changes were recorded for 12 months. In this way Rahman et al. (2001) tried to identify the first symptom expression and its progressive changes over time. But there is a big gap between primary and secondary causes of infection and symptoms for each particular Sundri tree. There is no scientific proof that pathogens are causing this top-dying of Sundri. Many of the scientists had made technical comments about pathological studies, but they did not find any scientific base for the correlation between pathogens and top- dying. Previous research had tried to find out the causal agents of top-dying of Sundri, and tried to determine the infectionbiology of the causal factors (pathogens) for top-dying of Sundri (Hartung et al. 1998; Chowdhury and Baksha, 1983, 1986; Rahman et al. 1983). Rahman et al. (2001) also tried to find out the biotic and abiotic factors responsible for aggravating the top-dying disease of Sundri. However, they failed to find out the real cause of top-dying of Sundri.

Hartung et al., (1998) reported their findings about the putative biotic disease agents of top-dying of Sundri in the Sundarbans. For the study, they collected 20 samples of wood, bark, and leaves from compartment 19, 22, 26, 32, and 39 in 1997. This study was conducted for the isolation of bacteria, and eight types of bacterial colonies were recorded. The color of bacteria colonies were white, yellow, red, white-yellow, yellow-white, yellow-brown, grey-white, shiny-white, etc. There was no yield of bacterial colonies from wood tissues taken from un-affected Sundri trees (3 samples). Samples of affected-dead-standing Sundri (2 samples), 4 unaffected wood samples of other tree species ( 2 from gewa, 1 from Passur, and 1 from Goran) were taken. Out of the 6 to 8 types of bacterial colonies, two isolates have been identified as Arthrobacter nicotianaes and Pseudomonas species due to their sequence homologies in a PCR assay. Both the species of bacteria were isolated from samples of severely top-dying affected living Sundri trees. The bacterial species showed phytopathogenic ability in a bioassay. The authors concluded a close association of phytopathogenic bacteria with topdying disease of Sundri (Hartung et al., 1998). But a thorough search of literature does not reveal any association of $A$. nicotianane with any other tree disease problem anywhere in the world. Moreover the data presented do not provide enough evidence of consistent association of Pseudomonas species with top-dying of Sundri wood. 
Although it is often difficult to pick out one predominant thread from the range of comments made by the respondents to this questionnaire, it is clear that top-dying is a very prevalent problem which respondents were familiar with and believed to be getting worse; that this led to the view that the Sundarbans was not currently in a healthy state; and its regeneration of trees was getting worse (Awal, 2007). The fact that several different reasons were cited as possible causes of top-dying and the lack of a clear starting point for the problem, suggest that the true causes are likely to be varied and gradual in their effects, and quite possibly several factors interact to lead to the problem (Awal, 2007). In connection with the causes of top-dying indicated by these local people, and with the indications of health problems and their causes, it must be remembered that these are indications of what people think, but that these perceptions of causes might not be valid (Awal, 2007); external verification of the causes is required (Awal, 2007). It is notable; however, that local residents as well as forestry workers were keen to see better management of the Sundarbans (Awal, 2007), for their benefit as well as of the environment (Awal, 2007). It is likely that local residents who benefit from the Sundarbans will have recommended sustainable management approaches, but probably were not the people recommending an outright ban on all use of the forests, as a few respondents did. These results are indicated as follows: if one number (all values in ppb) is given it is a mean, otherwise if a range is given they are the minimum and maximum; the number is followed by the type of material from which the data come, with no text indicating it is from sediments (the most common material reported in the literature); finally, the number in brackets indicates the numbered reference source, the sources being indicated in the legend (Table 1.0). Besides attempting to establish whether the element concentrations are elevated or not, it is valuable to explore whether there is any marked spatial (as opposed to random) variation in the concentrations found (table 1.0), and also the nutrient concentrations included in Tables 2.0, while table 3.0 includes similar results for water parameters. Table 1.0 details the results for analysis of the heavy metals data from tables 1 and table 2.The results from the analyses of soil parameters (Table 1.0) show many of the parameters tested to be markedly different in the different compartments but, except for soil $\mathrm{pH}$ (Awal, 2007), not to vary significantly either in the plot or in the interaction terms (Awal, 2007). Soil pH was, interestingly, highly or very highly significant with both factors and the interaction (Awal, 2007).It is not surprising that there are differences between the three compartments, as they had been selected in order to demonstrate a range of circumstances that might contribute to top-dying, such as nearness to human activity. As an example of the results shown in respect of this factor, The fact that there is no significant difference between plots for any parameters (other than $\mathrm{pH}$ ) may be an indication that there is little variation in these parameters over the relatively small distances between plots; or the selection of plots based on top-dying has not selected for variation in these parameters because they are not correlated with the amount of topdying (Awal, 2007).

It is interesting that there were no significant interactions (apart from soil $\mathrm{pH}$ ). This indicates that the effects evident between compartments can be considered independently of any plot effects-possibly operating at a broader geographical scale. Since soil $\mathrm{pH}$ showed significance in interaction as well as for the two factors separately, In general, it would appear that the higher the $\mathrm{pH}$ value, the higher the amount of top-dying (Awal, 2007). The pattern of variation between compartments is not consistent for the medium top-dying plots, but is consistent when comparing plots 1 and 3 in each compartment -compartment 31 having the highest $\mathrm{pH}$ (Awal, 2007).

There were no significant variations in any of the parameters for the water samples (Awal, 2007), for compartments or for plots, although water $\mathrm{pH}$ was close to significance (Awal, 2007) when comparing between plots (Table 2.0). This presumably implies that the water characteristics were quite consistent between different locations. This is, however, surprising given the significant differences in soil results in Table 1.0; for example, one might have expected water $\mathrm{Na}$ concentrations to vary in similar manner to soil $\mathrm{Na}$ values, since most of the soil $\mathrm{Na}$ has probably derived from that brought in by sea water. It is possible that soil $\mathrm{Na}$ reflects historical differences between compartments that are no longer evident in present daywater, i.e that water characteristics have changed notably in more recent periods (Awal, 2007).

The concentrations of the various heavy metals extracted from the soil samples, when analyzed by the two factors ANOVA with replication, gave rise to the results listed in Table 2.0. The majority of elements did not show any significant pattern to the results, for compartment, plot or interaction (Awal, 2007). However, seven elements, Bi, Exchangeable K, P, Sc, Sr and V, did show a significant difference between the three compartments (Awal, 2007), with compartment 26 having the greatest concentration of each of these elements and compartment 28 had the least (Awal, 2007). There were also a few other elements which showed results close to significance $(\mathrm{P}<0.10)$ which are also worth highlighting for further consideration (Awal, 2007), namely: Sb (plots were rather different); Ca (compartments showing variation); and In (both compartments and interactions were close to significance). With a large number of statistical tests, it is of course possible for occasional ones to be significant by chance; however, the proportion of tests which were significant or very close to it is higher than would be expected at random, and particularly with $\mathrm{Bi}$ and $\mathrm{V}$ the significance level was high (Awal, 2007), and therefore it can be started confidently that there are substantive variations in at least some of these chemical elements between different compartments and (with less confidence) some variations between plots(Awal, 2007). 
It is desirable to assess whether the chemical characteristics of soil or water have affected the growth of trees (Awal, 2007). Table 3.0 includes the results of Pearson's correlation analyses where the various parameters are being assessed for relationship with tree height data (Awal, 2007). Although correlation is not a method of analysis that presumes causality, it might nevertheless be justified in interpreting any significant correlation as evidence that the relevant chemical feature was causing an increase or decrease in tree height at higher values (Awal, 2007).However, none of the parameters tested showed a significant relationship with tree height, with exchangeable $\mathrm{Na}$ being the only element that even came close $(p<0.10)$ (Awal, 2007). Therefore, it does not appear that tree height is substantially affected by the parameters tested (Awal, 2007). It should be remembered that illicit felling of trees does occur in the areas studied (Awal, 2007), and it is possible that this extra factor might be influencing these results by selectively removing the largest trees, and making it more difficult for any correlation to be established (Awal, 2007).

Similar results may be demonstrated when comparing the same parameters with tree diameter (Table 3.0). In this case, however, not only exchangeable $\mathrm{Na}$ but also $\mathrm{Pb}$ gave results close to significance, while exchangeable $\mathrm{K}$ did reach the threshold of significance at the 5\% level (Awal, 2007). The negative correlation for $K$ shows that an increase in the amount of $\mathrm{K}$ is associated with a decrease in the girth of the trees. This is an unexpected result, as it might be expected that providing extra nutrients to the trees should lead to them growing better. It is unclear what might be leading to the relationship actually observed (Awal, 2007). A primary objective of the present work is to establish whether the concentrations of the various chemical elements, or other soil or water parameters, are having an influence on the amount of top-dying believed to exist in the different plots. To this end, correlations have been determined between the topdying index and the various parameters (Awal, 2007). The various heavy metal concentrations, arising from the ICP-MS work, were tested using Spearman's rank correlation coefficient, with the results included in Table 3.0. There were no elements which gave a significant correlation with the index of top-dying, although Sn gave a (negative) correlation which was close to significant $(\mathrm{p}<0.1)$. It is clear that, within the scope of the present samples and data collected, there is no indication that heavy metal concentrations are influencing the amount of top-dying, with the possible exception of $\mathrm{Sn}$ (Awal, 2007).

\section{Conclusions}

The overall conclusions from the results presented in this section are that the selection of sites has not produced clear statistical differences in the amount of top-dying evident; probably because of the way the data were collected (Awal, 2007). However, it is believed that there is notable variation between plots and compartments (Awal, 2007), and certainly this seems to be reflected in the ability of the trees to regenerate (Awal, 2007). However, the link between topdying and the size of the trees is not clear, with tree height and diameter not being directly related consistently to amount of top-dying, although moisture content of soil was inversely related (Awal, 2007). Since the great majority of trees present in all plots are the species Heritiera fomes, this means that the comments above are essentially referring to the response of this species rather than that of any others (Awal, 2007). Therefore, it was decided to test the Sn data, as well as data for a few other heavy metals (those with the strongest correlations in the previous tests), using the Pearson's correlation coefficient instead in order to assess how different the results would be if the data were treated as fully quantitative (Awal, 2007). The result for Sn has changed probability slightly, but sufficiently to become significant, while the result for $\mathrm{Pb}$ has moved to becoming less than 10\% significance (Awal, 2007). All other results were clearly non-significant (Awal, 2007). Consequently it may be concluded that there is very little in terms of chemical parameters that shows any clear relationship with the amount of top-dying, with $\mathrm{Sn}$ and possibly $\mathrm{Pb}$ being the only elements with any notable effect (Awal, 2007). It may also be concluded that, while use of the quantitative Pearson's correlation coefficient slightly increases the significance of the results, it does not substantially change the conclusions that arose from using the rank correlation technique (Awal, 2007).

Although there were only a few individual chemical elements which showed significant correlations with the amount of top-dying, there was evidence of elevated heavymetal concentrations of almost 14 elements out of 32 tested elements in the Sundarbans, which are likely to contribute to the increase in top-dying observed. There were also significant differences between different areas in the Sundarbans, and evidence of water supply problems to the system. Therefore, it is concluded that several factors are responsible for this increase in top-dying, rather than one specific factor only.

\section{References}

[1] Awal, M.A. (2007). Analysis of possible environmental factors causing top-dying in mangrove forest trees in the Sundarbans in Bangladesh. PhD thesis, University of Bradford.

[2] Awal, M.A., Hale, W.H.G. \& Stern, B. (2009). Trace element concentrations in mangrove sediments in the Sundarbans, Bangladesh. Marine Pollution Bulletin, 58(12), 1944-1948.

[3] Awal, M.A. (2014). "Correlation between the chemical composition of the surface sediment and water in the mangrove forest of the Sundarbans, Bangladesh, and the regeneration, growth and dieback of the forest trees and people health". Journal of Science Innovation; 2014. 2(2): pp.11-21.Science Publishing Group, USA; May 20th, 2014(2):11-21;doi: 10.11648/j/si.20140202.11. 
[4] Anonymous, 1975. Under-exploited tropical plants with promising economic value. National Academy of Sciences, Washington.

[5] Bangladesh Bureau of Statistics, 2006. Statistical Yearbook of Bangladesh, Statistics Division. Ministry of Planning. Dhaka, Bangladesh.

[6] Bari, A. 1993. Afforestation and the nutrient sink. Assistance to Fisheries Research Institute. Mymensingh. BGD / 89 / 012, Field Document-3.

[7] BFRI, 1990-95. Annual Research Report. Silviculture Genetics Division. Bangladesh Forest Research Institute (BFRI), Chittagong, Bangladesh.

[8] Briggs, J.C. (1991). Global species diversity. Journal of Natural History, 25:1403-1406.

[9] Burns, K.A; S. D. Garrity, and S.C. Levings. 1993. How many years until mangrove ecosystems recover from catastrophic spills? Marine Pollution Bulletin 26 (5): 239248.

[10] Chaffey, D. R; Miller, F.R; Sandom, J. H. 1985. A forest inventory of the Sundarbans, Bangladesh, Main report, Project Report No.140, 196 pp; Overseas Development Administration, London, U.K:195-196.

[11] Chantarasri, S. 1994. Integrated Resource Development of the Sundarban, Fisheries Resources Mangagement for the Sundarban, UNDP / FAO, BGD / 84 / 056, Khulna, Bangladeshp: 170-172.

[12] Currie, J. A. 1984. Gas diffusion through soil crumbs: the effects of compaction and wetting. Journal of Soil Science. 35: $1-10$.

[13] FAO / UNEP, 1981. Food loss Prevention in Perishable Crops. FAO Agricultural Services Bull, 43, Italy, Rome.

[14] FAO, 1982. Management and utilization of mangroves in Asia and the Pacific.1982. FAO Environment Paper, 3.Rome:160-168.

[15] FAO, 1994. Review of the state of world marine fisheries resources. FAO Fisheries resources. FAO Fisheries Technical Approach Paper 335:143.

[16] FAO, 1997. State of the World's Forests. Food and Agriculture Organization of the United Nations. Rome, Italy.

[17] Government of Republic of Bangladesh, 1985. The draft of (1985-90) 5th five year plan, Dhaka, Bangladesh.
[18] Government of Bangladesh, (1993). Forestry Master Plan: Executive Summary. Asian Development Bank, UNDP/FAOBGD/88/025, Forest Department, Government of Bangladesh, Dhaka.31p.

[19] Guha, R. (1989). Radical American Environmentalism and Wilderness Preservation: A Third World Critique. Environmental Ethics, 11, pp.71-83.

[20] Hambrey, J. 1999. Mangrove, Fisheries and Economic. Aquaculture and Aquatic Resource Management Program. Asian Institute of Technology. Thailand: 1-4.

[21] Hussain, Z. and Karim, A. (1994). Introduction. In: Mangroves of the Sundarbans. Volume 2: Bangladesh, Z. Hussain and G. Acharya (Eds.) IUCN. Bankok, Thailand. !$18 \mathrm{pp}$.

[22] Islam, A. K. M. N. 1973. The algal flora of the Sundarbans mangrove forest of Bangladesh. Bangladesh Journal of Botany. 2 (2): 11-36.

[23] Khan, J. A. 1997. Estimation of unregulated densities by line transects method in Gir forest, India. Tropical Ecology. 38(1): $65-72$.

[24] Mukharjee, A. K. 1975. The Sundarbans of India and its biota. Journal of Bombay Natural History Society, 72 (1):120.

[25] Phillips, O. L; Hall, P; Gentry, A.H.; Sawyer, S. A; and Vasques, R. 1994. Dynamics and species richness of tropical forests. Proc. Natural Acad. Society. U.S.A.91: 2805-2809.

[26] Seidensticker, J. Hai; A. 1983. The Sundarbans wildlife management plan: conservation in the Bangladesh (cited in Chaffey et al., 1985), Bangladesh.

[27] Seidensticker, J. \& Hai, M.A. 1983. The Sundarbans Wildlife Management. Bangladesh coastal zone. International Union for Conservation of Nature. Gland, Switzerland.

[28] Singh, K.P \& Singh, J.S. 1988. Certain structural functional aspects of dry tropical forest and savanna. International Journal of Ecology and Environmental Sciences 14:31-45.

[29] Sokal, R.R. and Rohlf, F.J. (1981). Biometry. San Francisco, w.H. Freeman.

[30] Status Report, Government of India, 1987; and India Remote Sensing Data (Nayak, 1993). Mangroves in India. India.

[31] UNESCO, 1997. Convention Concerning the Protection of the World Cultural and Natural Heritage, France, Paris. 